\title{
Mathematical modeling of a one-dimensional demographic process
}

https://doi.org/10.31713/MCIT.2020.33

\author{
Anatoliy Vlasyuk \\ Department of Economics, Mathematical \\ Modeling and Information Technologies \\ The National University of Ostroh Academy \\ Ostroh, Ukraine \\ anatoliy.vlasyuk@oa.edu.ua
}

\author{
Bohdan Krasiuk \\ Department of Economics, Mathematical \\ Modeling and Information Technologies \\ The National University of Ostroh Academy \\ Ostroh, Ukraine \\ bohdan.krasiuk@oa.edu.ua
}

\begin{abstract}
The specifics of the current stage of society connects with significant changes in directions and internal scales and interstate migration of the population. In this regard population migration processes between the two states are exploring in a onedimensional case. Now the scientific literature offers different mathematical models of these processes [1]. However, we will use diffusion models for modeling these processes.
\end{abstract}

Keywords- mathematical model, migration processes, population migration, one-dimentional case, population density, diffusion-convection model..

\section{INTRODUCTION}

The transition of Ukraine to a market economy takes place against the background of the migratory movement of the working-age population and requires constant monitoring and analysis and effective state regulation. External labor migration has become an important factor in shaping the national labor market.

Scientific works of scientists of different scientific directions are devoted to the study of migration processes. Theoretical and methodological aspects of migration research are analyzed in the works of domestic and foreign scientists.

A significant contribution to the development of scientific research labor migration of the population and economicmathematical modeling of territorial movement of the labor force was made by domestic scientists V. Vovk, V. Geets, V. Eleiko, O. Ovchinnikova, I. Ogirko, V. Priymak, V. Yurynets [1].

Analysis of publications on this issue gives grounds to conclude that the theoretical foundations of research and assessment of the impact of socio-economic factors on the migration climate of the region, models for forecasting migration and population of regions, monitoring the migration attractiveness of regions remain insufficiently developed.

Population migration is a complex process that is formed under the influence of various factors, including social, economic, psychological, demographic, legal, political, and other factors. Migration flows are an important factor in the formation of labor resources of the regions.
The development of effective migration policy is impossible without considering the existing trends in the territorial mobility of the population. Under such conditions, it is advisable to build predictive mathematical models of population migration flows.

\section{FORMULATION OF THE PROBLEM}

In this regard population migration processes in a onedimensional case. We will use diffusion-convection models for modeling these processes. In particular mathematical model of this problem in a one-dimensional case in conventional notation can be described by the following boundary value problem:

$$
\begin{gathered}
\frac{\partial}{\partial x}\left(D(x) \frac{\partial u}{\partial x}\right)-v \frac{\partial u}{\partial x}+\gamma_{1} u+\gamma_{2} u+f=\frac{\partial u}{\partial t} \\
\mu(\varphi) \frac{\partial \varphi}{\partial t}=\frac{\partial}{\partial x}\left(K(x, u, \varphi) \frac{\partial \varphi}{\partial x}\right), v=K(x, u, \varphi) \frac{\partial \varphi}{\partial x} \\
u(x, v)=\widetilde{U_{0}}(x), x \in(0, l) \\
l_{1} u(0, t)=\widetilde{U_{1}}(t), t>0 \\
l_{2} u(l, t)=\widetilde{U_{2}}(t), t>0 \\
{\left.\left[D(x) \frac{\partial u}{\partial x}-v(x) * u\right]\right|_{l=l_{i}}=0} \\
\left.\left(D(x) \frac{\partial u}{\partial x}-v(x) * u\right)\right|_{x=l_{i}+0}=\left.\left(D(x) \frac{\partial u}{\partial x}-v(x) * u\right)\right|_{x=l_{i}-0} \\
=r_{i}[u] .
\end{gathered}
$$

where $u=u(x, t)$ is density and population flows; $v(x)$ is population migration speed; $D(x)$ - population diffusion coefficient; $(2)$-determines the initial condition for population density; $\varphi(x, t)$ - the potential of the attractiveness of the population; $f$ - source of migration; $\gamma_{1}(x, t)$ - birth rate; $\gamma_{2}(x, t)$ - the mortality rate at point $x$ at time $\mathrm{t} ; l_{i}, i=1,2-$ operators which determines boundary conditions for density $\mathrm{u}$ at the ends of the segment $(0, l)$. 


\section{Modeling, control and information technologies -2020}

The boundary value problem (1) - (7) is a problem with discontinuous coefficients, since the diffusion coefficient $\mathrm{D}(\mathrm{x})$, population flow rate, $v(x)$ and coefficients $\gamma_{1}(\mathrm{x}, \mathrm{t})$, $\gamma_{2}(\mathrm{x}, \mathrm{t})$ tolerate discontinuities at points $x_{i}=l_{i} i=\overline{1, n}$ :

$$
\begin{gathered}
v(x)=v_{i}(x), x \in\left(l_{i}, l_{i+1}\right), D(x)=D_{i}(x), x \in\left(l_{i}, l_{i+1}\right), \\
\gamma_{k}=\gamma_{k}^{i}, x \in\left(l_{i}, l_{i+1}\right), i=\overline{0, n-1}, k=1,2 .
\end{gathered}
$$

For the task (1) - (7) it is constructed monotonic difference scheme by integro-interpolation method and founded its numerical solution [4].

We can improve the quality of analysis of the state of the migration system, to model and predict population migration based on the proposed model of studies of migration processes.

The software implementation of the corresponding computational algorithm is made in Python.

Numerical experiments were carried out on the basis of software implementation to obtain population density at any time.

A visual representation of the results of population density distribution across the region at different points in time is shown in Fig. 1.

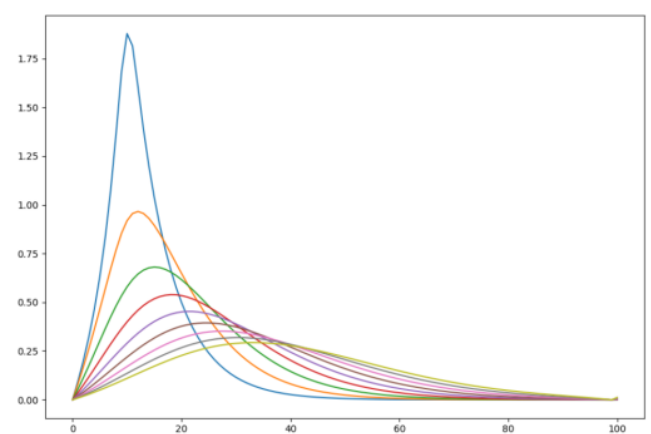
in time.

Fig. 1. Distribution of population density at different points

For the nonlinear boundary value problem (1) - (7) it is constructed monotonic difference scheme by integrointerpolation method and founded its numerical solution [4]. Also there is developed software and conducted experiments.
We can improve the quality of analysis of the state of the migration system, to model and predict population migration based on the proposed model of studies of migration processes.

Thus, the constructed mathematical model (1) - (7) makes it possible to predict population migration processes in the region at different moments of time for different boundary conditions, as well as for different potentials of potentials $\varphi_{1}$ at points $x_{i}=l_{i}$.

\section{CONCLUSION}

The problem of mathematical modeling of the one dimensional demographical process (aeration zone) is formulated. The nonlinear mathematical model of the population migration processes in one dimensional case is presented. The numerical solutions of the complicated nonlinear boundary value problem have been proposed. For the nonlinear boundary value problem (1) - (7) it is constructed monotonic difference scheme by integro-interpolation method and founded its numerical solution [4]. The software implementation of the corresponding computational algorithm is made in Python. In a series of numerical experiments, the influence of mass and heat transfer processes on moisture transfer and vice versa is analyzed.

\section{REFERENCES}

[1] Овчиннікова O.P. Проблеми управління міждержавними міграційними процесами на сучасному етапі // Придніпровський науковий Вісник (Донбаський випуск).- Економіка.- Донецьк, 1998.№108(175).- C.54-57

[2] Vlasyuk A.P., Krasiuk B.V. Mathematical modeling of migration processes of population in one-dimensional case/// A.P. Vlasyuk, B.V. Krasiuk // Abstract Internat. Conf. «Problems of decision making under uncertainties». - Lviv, Ukraine, 2019. - P. 111.

[3] Sergienko I.V., Skopetskiy V.V., Deineka V.S. Mathematical simulation and investigation of processes inhomogeneous in media. - Kiyv, Naukova Dumka, 1991

[4] Lyashko I.I., Makarov V.L., Skorobogatko A.A. The method of calculations. - Kyiv, 1977 - P. 408. 